\title{
O DESASTRE NA/DA BACIA DO RIO DOCE: VIOLÊNCIAS E VIOLAÇÕES SISTEMÁTICAS NO ÂMBITO DO (NEO)EXTRATIVISMO'
}

\author{
Claudia Marcela Orduz Rojas ${ }^{2}$ \\ Doralice Barros Pereira ${ }^{3}$
}

\begin{abstract}
Resumo: A barragem de rejeitos minerais de Fundão, da Samarco (Vale S.A/ BHP Billiton), em cinco de novembro de 2015, rompeu-se, deixando 19 mortos, milhares de atingidos e um rastro de destruição ao longo da Bacia do Rio Doce. Considerado o maior desastre relacionado com rompimento de barragens de rejeitos no Brasil - e um dos maiores do mundo -, a catástrofe interpela-nos pela extensão, magnitude e complexidade das perdas e danos, bem como pelas negligências e omissões sistemáticas por parte das empresas envolvidas. A partir da análise de três momentos, o artigo analisa a sobreposição de processos sociais, territorialmente circunscritos, violentos e supressores de direitos fundamentais, no âmbito do (neo)extrativismo. Concluímos que o colapso da barragem e a vivência do desastre revelam o contexto sistemático de violências e violações intrínsecas ao capitalismo extrativista, cujo padrão de acumulação destrói naturezas, territórios, culturas e vidas.
\end{abstract}

Palavras-chave: Barragem de Fundão; Desastres; Capitalismo Extrativista; (neo)extrativismo; Bacia do Rio Doce.

Abstract: Samarco's Fundao mineral tailings dam (Vale S.A / BHP Billiton), on November 5, 2015, collapsed and caused 19 deaths and damages to thousands as it left a trail of much greater destruction along the Rio Doce Basin. Considered the largest disaster related to tailings dam in Brazil - and one of the largest in the world - the catastrophe challenges us to reflect upon the extent, magnitude and complexity of losses and damages as well as the systematic negligence and omissions on the part of the companies involved. From the analysis of three moments, the article analyzes the overlapping issues of social processes - territorially circumscribed - violent and suppressive of fundamental rights, in the scope of (neo) extractivism. We conclude that the collapse of the dam and living with the disaster reveal the systematic context of violence and intrinsic abuses of extractive capitalism, whose pattern of accumulation destroys environments, territories, cultures and lives.

Keywords: Fundão Mineral Tailings dam; Disaster; Extractive Capitalism; (neo)extractivism; Rio Doce Basin.

\footnotetext{
${ }^{1}$ Este artigo deriva das reflexões de uma tese de doutorado em andamento, da Pós-Graduação em Geografia da UFMG, intitulada Do caos à lama e da lama aos caos: a gestão corporativa do desastre na/da Bacia do Rio Doce.

2 Doutoranda em Geografia pela Universidade Federal de Minas Gerais (UFMG). claudiaorduzrojas@gmail.com

${ }^{3}$ Docente do Departamento de Geografia da Universidade Federal de Minas Gerais (UFMG). pereiradb@yahoo.com.br.

Estudos Geográficos, Rio Claro, 17(1): 6-31, jan./jun. 2019 (ISSN 1678-698X) http://www.periodicos.rc.biblioteca.unesp.br/index.php/estgeo
} 


\title{
INTRODUÇÃO
}

\begin{abstract}
Vamos festejar a inveja, a intolerância e a incompreensão. Vamos festejar a violência e esquecer a nossa gente, que trabalhou honestamente a vida inteira e agora não tem mais direito a nada. Vamos celebrar a aberração de toda a nossa falta de bom senso. Nosso descaso por educação.
\end{abstract}

(Renato Russo)

Nas últimas décadas do século $\mathrm{XX}$, o Brasil e a América Latina, de maneira geral, (re)ssurgiram como novos nichos no/do processo de (re)estruturação e (re)acomodação do capital global (TEUBAL, PALMISANO, 2012). Esse processo está vinculado à crise de superacumulação do capitalismo, iniciada no final da década de 1960, que exigiu um novo ajuste socioespacial e (re)organização do capital global. A busca por atividades lucrativas, a exaustão dos recursos naturais e a pressão dos movimentos ambientalistas nos países centrais, aliadas ao aumento progressivo da demanda por minérios e ao "ajuste neoliberal", tornaram a América Latina uma nova fronteira de expansão e acumulação, para onde foram transferidos enormes volumes de capitais excedentes, outorgando mais um fôlego ao capital (CARNEIRO, 2016). Nesse contexto, a região abandonou suas aspirações industrialistas e intensificou sua inserção subordinada e funcional ao sistema-mundo, através da extração e exportação de bens primários (CARNEIRO, 2016; ROJAS, 2014; GUDYNAS, 2012).

A partir da década de 1990, a região passou a receber uma avalanche de investimentos internacionais e nacionais, que reclamam e geram, ao mesmo tempo, dinâmicas e transformações econômicas, territoriais, ambientais, sociais, entre outras. Esse processo se acentuou na primeira década do século $X X I$, em virtude do crescimento da demanda externa por commodities minerais (principalmente por parte da China) e valorizou as commodities no mercado global.

$\mathrm{Na}$ América Latina, o Brasil representa o caso mais paradigmático. A intensificação da extração de recursos fez do país, rapidamente, o maior extrativista da América Latina (GUDYNAS, 2012), o segundo maior produtor de minério de ferro do mundo ${ }^{4}$ e um dos mais importantes global players na produção mineral mundial. Aqui, o avanço da frente minerária ancora-se no (neo)extrativismo, uma versão contemporânea do extrativismo tradicional, que faz prevalecer a inserção subordinada e funcional à economia capitalista globalizada. Nesse paradigma, novos e velhos elementos estruturantes do extrativismo tradicional mesclam-se. Entre as novidades introduzidas pelo (neo)extrativismo, destacam-se a maior participação do estado (ativismo estatal) nos resultados econômicos, a elevação da tributação dos royalties e a ampliação de investimentos em programas de transferência de renda destinados a reduzir a pobreza.

\footnotetext{
4 "Enquanto as mineradoras reclamam da elevação de custos em meio à crise, seus resultados têm gerado receitas para o país. Somente em 2017, a exportação de minérios respondeu por $13 \%$ da pauta de exportações brasileiras. De acordo com dados do Ministério de Desenvolvimento, Indústria e Comércio Exterior (MDIC), o principal produto mineral exportado pelo Brasil em 2017 foi o minério de ferro: o montante foi de mais de US\$ 19 bilhões, o que corresponde ao volume de 383,5 milhões de toneladas. O principal destino foi a China, com 56\% do volume exportado pelo Brasil” (IBRAM, 2018).

Estudos Geográficos, Rio Claro, 17(1): 6-31, jan./jun. 2019 (ISSN 1678—698X) http://www.periodicos.rc.biblioteca.unesp.br/index.php/estgeo
} 
Em linhas gerais, essa nova modalidade exige a extração de recursos naturais em grande volume ou alta intensidade (medidos geralmente em bilhões ou milhões de toneladas/barris), ou seja, numa escala de exploração e geração de rejeitos sem precedentes na história. Diante da magnitude dos empreendimentos, esses volumes igualmente exigem uma maior infraestrutura espacial, como pátios para manobras, barragens de rejeitos e dutos para transferência dos fluxos de minérios em direção aos portos. Os recursos extraídos, orientados principalmente à exportação como matériasprimas, participam de um modelo de desenvolvimento subordinado às demandas globais e à volatilidade dos preços internacionais das commodities. Além disso, os recursos (minerais, petróleo, soja, carne, etc.) não passam por grandes processos industriais ou passam por um processamento mínimo ou limitado, como no caso das pelotas de minério de ferro (GUDYNAS, 2012; 2016).

Adicionalmente, nessa nova modalidade de acumulação, os processos de extração e exportação são controlados principalmente por grandes corporações transnacionais (GUDYNAS, 2012; PETRAS, 2014), que operam em escala global. Conhecidos por extrativismos de terceira e quarta gerações, eles requerem um maior uso de capital, a transferência de tecnologia, o alto consumo de água e energia, o uso de substâncias tóxicas e a remoção de grandes volumes de recursos, com o descarte de parte significativa destes [ocasionando passivos imperfeitamente acondicionados]. Em virtude da intensidade e do volume de extração de recursos, esses extrativismos ocasionam impactos ambientais e sociais mais amplos (GUDYNAS, 2016), que transcendem a escala local e se propagam por várias regiões.

Contudo, apesar da maior participação do Estado nos resultados econômicos, a adoção desse novo padrão extrativista de acumulação reproduz as contradições estruturantes, em termos sociais, próprias do modelo extrativista (GUDYNAS, 2012; MALERBA et al., 2012). Trata-se de um "modelo bio-depredador por excelência" (ACOSTA, 2011), que agride sistemática e massivamente a natureza e engendra, fomenta e reproduz múltiplas formas de violência, repressão e autoritarismo (lbid., 2011). Um paradigma de acumulação por espoliação, (HARVEY, 2005) assentado em processos de pilhagem e altas doses de violência (CANTALAPIEDRA, 2018; ACOSTA, 2011), sendo a última não só um elemento estrutural como também condição necessária para sua continuidade e aprofundamento. Desencadeada pelo Estado e/ou por empresas transnacionais - atores geralmente alinhados -, a violência é/está inerente às economias extrativistas e se reatualiza e manifesta de diversas formas, tornando-se cada vez mais presente e explosiva. Convertido em uma das principais forças motrizes da economia, o capitalismo extrativo (PETRAS, 2014) conduz a região a um processo de reprimarização, produz efeitos derrame (GUDYNAS, 2016) e gera consequências socioespaciais e ambientais nefastas, dado o seu modo específico/excludente de apropriação da natureza (ROJAS, PEREIRA, DIAS, 2018; ZHOURI et al., 2016a).

Nos últimos anos, esses efeitos acentuaram-se sobremaneira em virtude da dependência e volatilidade dos preços internacionais das commodities minerais, que exigiram novos reajustes e manobras por parte das grandes empresas, para manter as taxas de lucros, ou ir além delas. A diminuição dos investimentos e custos operacionais em áreas como saúde e segurança, entre outras, apresentaram-se como saídas rápidas e transitórias para superar a desvalorização dos preços das matérias primas no mercado internacional (WANDERLEY et al., 2016). Entretanto, essas estratégias, que Estudos Geográficos, Rio Claro, 17(1): 6-31, jan./jun. 2019 (ISSN 1678—698X) http://www.periodicos.rc.biblioteca.unesp.br/index.php/estgeo 
se desenvolvem num contexto sistemático de violências e violações de direitos, deflagraram novas contradições e crises.

O rompimento da barragem de rejeitos de Fundão ${ }^{5}$, de propriedade da Samarco (Vale/BHP Billiton), em 05 de novembro de 2015, bem como a consequente gestão do desastre, constituem um cenário profícuo para se entender melhor tais fenômenos. 0 presente texto foi organizado em três partes: a primeira traz a sequência de processos e decisões corporativas que contribuíram para o colapso da barragem e diminuíram a capacidade dos afetados para prevenir ou afrontar perturbações súbitas coletivas; a segunda retrata as características da ocorrência do evento, ou seja, o rompimento do reservatório de Fundão e a chegada da lama até o oceano; a terceira analisa as ações emergenciais, omissas e negligentes, acionadas pela empresa e pelo Poder Público, que contribuíram para que a crise (social) aguda se tornasse crônica.

\section{O FIM DO SUPERCICLO DAS COMMODITIES E O COLAPSO DA BARRAGEM DE FUNDÃO}

A barragem de Fundão pertence à Samarco S.A., uma empresa brasileira criada no ano de 1977, voltada a abastecer o mercado global com pelotas de minério de ferro produzido a partir da transformação de minério de baixo teor. Controlada em partes iguais por dois acionistas, Vale S.A. e BHP Brasil Ltda., a empresa se tornou líder nacional em ações de responsabilidade socioambiental e na adoção de altos padrões de segurança nas suas operações. A Samarco detém prêmios e reconhecimentos nacionais e internacionais (como a melhor empresa para trabalhar, maior mineradora do Brasil, empresa verde, entre outros). Ela foi também a primeira mineradora mundial a ter a certificação ISO 14001 (de gestão ambiental), concedida em 1998 para todas as suas etapas de produção. ${ }^{6}$ Durante vários anos, a Samarco também fez parte do seleto grupo das maiores empresas de mineração do Brasil (ROJAS, PEREIRA, 2017).

A posição privilegiada no ranking nacional esteve associada à expansão da sua capacidade de produção, principalmente a partir de 2012, quando a empresa optou por aumentar a produção de pelotas, para compensar a queda do preço do minério de ferro no mercado internacional e garantir taxas crescentes de lucros a seus acionistas. 0 aumento da produção foi alcançado rapidamente por meio de diversas estratégias: a primeira consistiu na execução do Projeto Quarta Pelotização, que permitiu à Samarco elevar sua capacidade de produção em 37\%; a segunda voltou-se a redução de custos

\footnotetext{
${ }^{5}$ A Portaria $\mathrm{n}^{\mathrm{0}} 416$ de 2012, do Departamento Nacional de Pesquisa Mineral (DNPM), define as barragens de mineração como "barragens, barramentos, diques, reservatórios, cavas exauridas localizados no interior da área concedida ou área de servidão, utilizados para fins de contenção, acumulação ou decantação de rejeitos de mineração, descarga de sedimentos provenientes de atividades de mineração, com ou sem captação de água associada, compreendendo a estrutura do barramento e suas estruturas associadas". As barragens de rejeitos também integram o escopo da Política Nacional de Segurança de Barragens (PNSB), criada no ano de 2010, que dispõe sobre barragens destinadas à acumulação de água, à disposição final ou temporária de rejeitos e à acumulação de resíduos industriais. As barragens incluídas na Política Nacional devem apresentar pelo menos uma das seguintes características: altura do maciço maior ou igual a 15 metros, capacidade do reservatório maior ou igual a três milhões de metros cúbicos, reservatório com resíduos perigosos e dano potencial associado, médio ou alto em termos econômicos, sociais, ambientais ou de perda de vidas humanas (PNSB, 2010).

${ }^{6}$ Site da Samarco (2016b) e Samarco (2016c).

Estudos Geográficos, Rio Claro, 17(1): 6-31, $\quad$ jan./jun. $2019 \quad$ (ISSN $1678-698 X)$ http://www.periodicos.rc.biblioteca.unesp.br/index.php/estgeo
} 
operacionais, através da combinação de alta da produtividade, uso máximo de ativos e aumento da eficiência. Tais estratégias possibilitaram acrescer o volume de produção e vendas em 15,5\% em 2014; diminuir o custo de produção (de US\$ 57,11 em 2013 para US\$ 53,2 em 2014), mitigar as perdas relacionadas à precificação do minério de ferro e manter a receita em patamares elevados (SAMARCO, 2014).

Apesar do ambiente hostil do mercado global de commodities minerais, os resultados econômicos alcançados pela empresa nos últimos anos foram excepcionais. Em 2013, por exemplo, a empresa alcançou o maior faturamento de sua história, com um aumento de 3,2\% no lucro em relação ao ano anterior (MPF, 2016). Em 2014, atingiu o recorde de 25,075 milhões de toneladas (Mt) de pelotas e galgou um lucro líquido de $\mathrm{R} \$ 2,805,5$ milhões (Ibid., 2014). Em 2015, a empresa acumulou novos recordes de produção e lucros, que foram subitamente interrompidos pelo colapso da barragem e consequente paralisação de suas atividades.

A barragem de rejeitos de Fundão integra o Complexo Minerário de Germano, localizado no município de Mariana, na região central do estado de Minas Gerais (SAMARCO, DOSSIÉ, 2016a). O reservatório começou a ser construído no final de 2005, para estocar os rejeitos derivados do processo de extração e beneficiamento do minério de ferro. A barragem entrou em funcionamento três anos depois, com uma capacidade de estocagem de 55 milhões de $\mathrm{m}^{3}$ de rejeitos (lbid., 2016a). Não obstante, conforme revelou o procedimento investigatório criminal instaurado pelo Ministério Público Federal (MPF), desde a fase de sua construção, a estrutura possuía situações típicas de incremento de riscos não permitidos, ou seja, problemas, falhas ou "não conformidades" que não receberam a devida atenção nem foram integralmente corrigidas (MPF, 2016). Tais riscos estavam associados a problemas na drenagem não solucionados integralmente, ao uso de material de baixa qualidade na construção da barragem, ao monitoramento deficiente e à falta de controle da quantidade de rejeitos despejados no reservatório (MARQUES, BERTONI, 2016). Ademais, a barragem apresentou outras anomalias relacionadas com obras na estrutura que careciam de projeto, diminuição de investimentos em geotécnica entre 2012 e 2015 e contratação de uma empresa de consultoria, a VogBR, que carecia de capacidade técnica para emitir laudos que atestassem a estabilidade da represa (Ibid., 2016).

De acordo com análise das atas de reuniões da Samarco realizadas entre 2007 (quando recebe a Licença de Instalação) e 2015, os executivos da empresa e da Vale S.A. e BHP Billiton participaram das reuniões e Conselhos e estavam cientes das falhas, problemas e "não conformidades" que apresentava a represa e da probabilidade de ocorrência de uma tragédia. Todavia, esses representantes e diretores ignoraram os registros ou não dispensaram a devida importância, necessária a uma situação que poderia levar a tão grave desfecho. Ao contrário, houve pressão para aumentarem a produção, e, consequentemente, a quantidade de rejeitos liberados e acumulados, acentuando sobremaneira o risco de colapso da represa, materializado oito anos depois (MPF, 2016).

Ainda segundo o MPF, os executivos das empresas desprezaram as recomendações e estudos elaborados pelo próprio projetista do reservatório (que, um ano antes do rompimento, alertou sobre um princípio de ruptura na represa) e por consultores e técnicos contratados pela Samarco. Exemplo disso foi o descumprimento das recomendações do Manual de Operação - que estava desatualizado -, incorrendo Estudos Geográficos, Rio Claro, 17(1): 6-31, jan./jun. 2019 (ISSN 1678—698X) http://www.periodicos.rc.biblioteca.unesp.br/index.php/estgeo 
em falhas operacionais graves (MPF, 2016). Outro exemplo ilustrativo desse modus operandi foi o cumprimento parcial de recomendações que deveriam garantir a estabilidade da estrutura, emitidas pelo Independent Tailings Review Board (ITRB), uma consultoria contratada pela própria Samarco, constituída por especialistas nacionais e internacionais, que recomendaram práticas operacionais e de gestão de risco da barragem. Por sinal, uma das recomendações do ITRB descumprida integralmente pela empresa foi o reassentamento do subdistrito de Bento Rodrigues (MPF, 2016), povoado que foi totalmente destruído pela lama que irrompeu de Fundão, e cuja população era constituída majoritariamente por negros e pardos (WANDERLEY, 2015), o que sugere mais uma "irresponsabilidade organizada" por parte das elites (ACSELRAD, 2018, p.160). Somam-se a essas posturas, recomendações sistematicamente negligenciadas por parte do projetista da barragem (MPF, 2016), bem como alertas emitidos pela sociedade civil e grupos comprometidos com 0 interesse geral (ACSELRAD, 2018).

Esses descumprimentos sistemáticos e planejados por parte da Samarco tornaram-se ainda mais graves em função dos alertas contidos em um estudo de risco encomendado pela própria empresa. Segundo o MPF, o documento previa, em caso de rompimento da barragem, a possibilidade de causar até 20 mortes $^{7}$, impactos ao meio ambiente por mais de 20 anos, colapso social, impactos ao patrimônio cultural nacional, entre outros. A exatidão das previsões registradas no documento chega a ser ofensivo, conforme registros da Figura 1:

\begin{tabular}{|c|c|c|c|c|c|c|}
\hline $\begin{array}{c}\text { Saúde e } \\
\text { segurança }\end{array}$ & $\begin{array}{c}\text { Meio } \\
\text { ambiente }\end{array}$ & Comunidade & Reputação & Legal & Financeiro & $\begin{array}{l}\text { Fator de } \\
\text { severidade }\end{array}$ \\
\hline $\begin{array}{l}>20 \text { fatalidades. } \\
\text { Incapacidade } \\
\text { permanente } \\
(>30 \% \text { do } \\
\text { corpo) a mais de } \\
100 \\
\text { pessoas. }\end{array}$ & $\begin{array}{l}\text { Impacto grave } \\
(>20 \\
\text { anos) à terra, } \\
\text { biodiversidade, } \\
\text { serviços } \\
\text { ambientais, } \\
\text { recursos hidricos } \\
\text { ou ar. }\end{array}$ & $\begin{array}{c}\text { Colapso parcial } \\
\text { da ordem social. } \\
\text { Dano } \\
\text { generalizado a } \\
\text { itens da } \\
\text { cultura global. } \\
\text { Infraçâo muito } \\
\text { séria ao } \\
\text { patrimônio } \\
\text { cultural. } \\
\text { Empresa } \\
\text { diretamente } \\
\text { responsável ou } \\
\text { cúmplice de } \\
\text { impacto severo } \\
\text { aos direitos } \\
\text { humanos. }\end{array}$ & \begin{tabular}{|c|} 
Repúdio pela \\
midia e varias \\
ONGs. Ação \\
direta da \\
empresa \\
(incluindo açōes \\
de \\
parceiros/ \\
contratados) \\
resultando em \\
problemas de \\
reputaçāo. \\
Grandes protestos \\
violentos ( $>100$ \\
pessoas) \\
resultando em \\
fatalidades.
\end{tabular} & $\begin{array}{l}\text { Perda da licençąa } \\
\text { de operação } \\
\text { válida. } \\
\text { Encerramento } \\
\text { forçado } \\
\text { da operaçãa. } \\
\text { Processo de ato } \\
\text { de concentraçầo } \\
\text { ou inquérito de } \\
\text { práticas de } \\
\text { corrupção no } \\
\text { exterior. }\end{array}$ & $\begin{array}{c}\text { USD } 250 \text { milhões } \\
\text { - USD } 2,5 \\
\text { billhōes }\end{array}$ & 300 \\
\hline \multicolumn{7}{|c|}{$\begin{array}{l}\text { Figura 74: Extraído da fl. } 18 \text { do Manual de Riscos Corporativos, que consta na pasta M - Política e manual, no } \\
\text { DVD de fl. } 268 \text { - Anexo II Vol. } 2 \text {, do PIC } n^{\circ} 1.22 .000 .03490 .2015-78 \text {. }\end{array}$} \\
\hline \multicolumn{7}{|c|}{$\begin{array}{l}\text { A precisão do documento chega a ser chocante! Na coluna "Saúde e segurança", } \\
\text { percebe-se que havia a previsão da morte de cerca de } 20 \text { pessoas, caso houvesse o } \\
\text { rompimento da barragem de Fundão, quase exatamente o número de vítimas pelo qual } \\
\text { respondem os denunciados (19 mortes). }\end{array}$} \\
\hline
\end{tabular}

Figura 1 - Manual de Riscos Corporativos da Samarco (2011).

Fonte: MPF (2016, p. 185)

\footnotetext{
${ }^{7}$ A exposição e força da lama tóxica também causou o aborto de um feto de três meses, não reconhecido como $20^{\mathrm{a}}$ vítima pela empresa (SENRA, 2016).

Estudos Geográficos, Rio Claro, 17(1): 6-31, jan./jun. $2019 \quad$ (ISSN $1678-698 X)$ http://www.periodicos.rc.biblioteca.unesp.br/index.php/estgeo
} 
Ademais, constatou-se a existência de anomalias e problemas graves no Plano de Segurança da Barragem de Fundão. Em outras palavras: a Samarco operava em desacordo com o estabelecido na legislação, especificamente a Política Nacional de Segurança de Barragens (2010) e a Portaria do Departamento Nacional de Pesquisa Mineral (DNPM) $n^{\circ} 416$, de 03 de setembro de 2012. O descumprimento de normas e instrumentos, contudo, não se restringiu apenas a questões de ordem técnica e tecnológica. Questões de ordem social e humanitária, como a elaboração, envio e execução do Plano de Ação Emergencial (PAE), que integra o Plano de Segurança da Barragem, também foram desconsideradas e negligenciadas pela empresa (POLÍCIA CIVIL, 2016). Apesar do PAE e do Plano de Ação de Emergência das Barragens de Mineração (PAEBM) serem exigidos pelo DNPM para barragens consideradas de Dano Potencial Associado Alto, ${ }^{8}$ a Polícia Civil constatou que a Samarco não se preocupou em estabelecer comunicação eficaz com as comunidades à jusante. Ela foi imprudente, especialmente com os moradores do povoado de Bento Rodrigues, presentes na área de autossalvamento, portanto, sob responsabilidade da empresa, conforme previsto também na Portaria 526/13 do DNPM. Além disso, a Samarco não instalou sirenes ou avisos luminosos no povoado, o que poderia ter minimizado os danos e/ou salvo vidas. Submetidos a um processo de vulnerabilidade acentuado, trabalhadores e moradores estavam despreparados para lidar com uma catástrofe dessa magnitude.

Conforme desvendaram os investigadores, falhas e problemas estruturais recorrentes, estudos que previam vítimas e danos ambientais irreversíveis, requisitos e normas estipuladas na legislação e recomendações e alertas que previam uma tragédia, emitidos por projetistas, técnicos e cidadãos, sucumbiram à política de expansão da produção e incremento dos resultados econômicos positivos para os acionistas. Essa escolha política sustentou-se na "redução de custos de produção", no "esforço na eficiência do processo", no incremento dos "ganhos de produtividade", na "austeridade na gestão de custos de produção", e, portanto, na diminuição da tomada de medidas que garantissem maior e melhor segurança, mantida em segundo plano pela empresa (MPF, 2016, p.191). É importante lembrar que essa política de "redução dos custos de produção" se intensificou a partir de 2012, no período conhecido como pós-boom, quando teve início a queda acentuada do preço do minério de ferro no mercado mundial.

Por conseguinte, para compensar a diminuição do preço das commodities, as empresas optaram por "ajustar" suas operações, aumentando o volume da produção e reduzindo custos operacionais (WANDERLEY et al., 2016). A "austeridade nos custos de produção" incidiu, principalmente, sobre os investimentos na área de saúde e segurança. Em relação ao componente saúde, os cortes propiciaram a intensificação no ritmo do trabalho e o aumento da taxa de acidentes que saltou de 0.49 para 1,27 entre 2011 e 2014. Já entre 2013 e 2014 "a participação de componentes de segurança e saúde foi reduzida de 3,8\% para $2,8 \%$ do total de investimentos de capital" (Ibid., 2016, p. 55-56). Em relação ao componente segurança, os cortes afetaram investimentos na área de geotécnica - que entre 2012 e 2015 tiveram uma queda de 29\% - e na de gestão de risco da barragem, que acabou resultando no colapso da represa. Tal

\footnotetext{
${ }^{8}$ O PAEBM está regulamentado na Política Nacional de Segurança de Barragens (PNSB), no art. $8^{\circ}$ da Portaria $n^{\circ} 416$, de 3 de setembro de 2012, e na Portaria n ${ }^{\circ}$ 526, de 09 dezembro de 2013, ambas do DNPM.

Estudos Geográficos, Rio Claro, 17(1): 6-31, jan./jun. $2019 \quad$ (ISSN $1678-698 X)$ http://www.periodicos.rc.biblioteca.unesp.br/index.php/estgeo
} 
"ajuste" econômico, portanto, desencadeou inúmeras mortes, danos e perdas sociais e ambientais e deflagrou uma sucessão de crises agudas pontuais ao longo da Bacia do Rio Doce, analisadas a seguir.

\section{DE NOVEMBRO DE 2015: UM DIA PARA NUNCA MAIS ESQUECER}

O cinco de novembro de 2015 é um dia para nunca mais esquecer. Essa data divide, em antes e depois, a vida de milhares de atingidos, a paisagem da Bacia do Rio Doce, a história ambiental do Brasil e a história recente da mineração mundial. Naquele dia, por volta das $15 \mathrm{~h} 45 \mathrm{~min}$, um forte estrondo foi ouvido nas proximidades de Fundão, uma das três barragens de rejeitos da mineradora Samarco, localizada no município de Mariana, região central do estado de Minas Gerais. Em pouco tempo, foram liberados 39,2 milhões de $\mathrm{m}^{3}$ de rejeitos, que atingiram de maneira mais dramática funcionários que trabalhavam nas imediações da barragem e moradores do subdistrito de Bento Rodrigues, situado a quatro km a jusante do reservatório (SAMARCO, BOOK, 2016b). Ao todo, foram registradas 19 vítimas fatais: 14 eram funcionários que trabalhavam nas imediações da estrutura, 13 deles de empresas terceirizadas da Samarco, que faleceram por asfixia, afogamento, politraumatismo e mal súbito. Da própria empresa, morreu um único trabalhador, cujo corpo nunca foi encontrado (MTPS, 2016). Quatro das outras cinco vítimas eram moradores de Bento Rodrigues e morreram por asfixia e afogamento. A exposição e força da lama tóxica também provocou o aborto de um feto de três meses, que não foi reconhecido como 20avítima pela empresa (SENRA, 2016).

Segundo o inquérito da Polícia Civil, os corpos das vítimas revelaram a violência do fluxo da lama. Alguns desses corpos foram fragmentados ao se chocarem com outras estruturas; outros perderam as vestes; outros ainda foram encontrados a 110 quilômetros de distância (PCMG, 2016). Os sobreviventes do povoado de Bento Rodrigues que conseguiram escapar da enxurrada de lama, apesar de não serem avisados pela empresa, passaram a noite na parte alta do povoado. No dia seguinte, eles foram levados para a Arena Mariana, local escolhido pela Prefeitura Municipal como abrigo temporário. Após alguns dias, as famílias foram progressivamente sendo realocadas pela Samarco em hotéis e pousadas da cidade (GMG, 2015), e posteriormente transferidas para casas temporárias, alugadas pela empresa, onde moram até hoje esperando a reconstrução de um novo Bento Rodrigues ${ }^{9}$.

A força, velocidade e violência da lama também destruíram parcialmente os distritos de Paracatu de Baixo, distante 40 km da Barragem de Fundão; Gesteira, localizado a $62 \mathrm{~km}$, e a sede do município de Barra Longa, distante $76 \mathrm{~km}$ do reservatório. Após alcançar o córrego Santarém e os rios Gualaxo do Norte e Carmo, a onda da lama de rejeitos foi perdendo sua potência de destruição, mas seguiu provocando outros danos e perdas sociais e ambientais. Passados 16 dias e $650 \mathrm{~km}$ percorridos ao longo dos estados de Minas Gerais e Espírito Santo, a pluma de rejeitos

\footnotetext{
${ }^{9}$ A reconstrução do novo Bento será efetuada numa localidade conhecida como Lavoura, a nove km do povoado destruído. O processo de terraplanagem foi iniciado em agosto de 2018 e a entrega das moradias está prevista para o primeiro semestre de 2020, ou seja, cinco anos depois do rompimento da barragem.

Estudos Geográficos, Rio Claro, 17(1): 6-31, jan./jun. $2019 \quad$ (ISSN $1678-698 X)$ http://www.periodicos.rc.biblioteca.unesp.br/index.php/estgeo
} 
(nome dado pelo jargão científico) encontrou o Oceano Atlântico e se alastrou rapidamente, afetando ainda áreas no Sul da Bahia e norte do Rio de Janeiro. Nesse percurso, Áreas de Preservação Permanentes (APP), Unidades de Conservação (UC), Terras Indígenas $(\mathrm{TI})$, assentamentos rurais e pequenas e médias cidades foram prejudicados em intensidades diferentes de acordo com a proximidade da barragem e a dependência material e simbólica do rio e do mar (IBAMA, 2015).

Todas as localidades atingidas pela lama de rejeitos ficaram impossibilitadas de usar a água do Rio Doce para o consumo humano, dessedentação de animais, irrigação de lavouras, pesca e lazer durante dias, semanas e meses (IBAMA, 2015). E assim continuam até hoje. Para minimizar e administrar as crises nesses municípios, foi requisitada a intervenção do Exército Brasileiro, principalmente de atiradores do Tiro de Guerra e da Companhia de fuzileiros, que ajudaram na coordenação e distribuição de água tratada para a população durante algumas semanas (G1-ES, 2015a).

Em cidades como Governador Valadares (MG), com uma população de aproximadamente 300 mil habitantes, o caos foi generalizado. Após a Samarco ser obrigada pela Justiça Federal a fornecer água para a população, a empresa enviou o primeiro carregamento de água potável - cerca de 280 mil litros - em um trem contaminado com querosene. Com isso, a água dos vagões e dos caminhões-pipas que a distribuía teve que ser totalmente descartada (GABINETE MILITAR DO GOVERNADOR, 2015). Uma vez superado o "impasse", a empresa não forneceu água mineral suficiente para toda a população, conforme estabelecido no Plano Emergencial elaborado pela prefeitura. Assim, o ente público foi obrigado a disponibilizar postos de distribuição de água engarrafada, que eram escoltados pelo Exército (KAWAGUTI, SENRA, 2015a). Para conseguir a cota individual diária (cinco litros por pessoa), os valadarenses foram obrigados a permanecer em longas filas e esperar até duas horas, sob sol forte, durante sete dias. Com a normalização gradativa do serviço, por meio da abertura de poços artesianos e tratamento da água (superficial) com o polímero de acácia negra ${ }^{10}$, os moradores passaram a beber e utilizar água com cor, gosto e cheiro ruins em função da presença de metais, sem falar da insegurança sobre os efeitos nocivos para sua saúde a médio e longo prazos.

Em Colatina (ES), a situação não foi diferente. Com uma população de pouco mais de 120 mil habitantes, a cidade capixaba viveu dias de caos em decorrência da falta de água, sendo requisitada também a presença do Exército e da Polícia Militar (BRAGA, CELESTINO, 2015). A população também teve que enfrentar longas filas, durante cinco dias, para ter acesso à água mineral e potável distribuída pela Samarco. Apesar da possibilidade de riscos iminentes para a saúde, denunciados pelo Ministério Público Federal, pelo Ministério Público Estadual do Espírito Santo (MPES) e pelo Ministério Público do Trabalho (MPT), o serviço público de abastecimento e distribuição de água foi restabelecido gradativamente após a Samarco afirmar que a água tratada com a acácia negra era apta para o consumo humano e doméstico (SAMARCO, DOSSIÊ, 2016a).

\footnotetext{
${ }^{10}$ De acordo com a Samarco, a acácia negra é um coagulante orgânico à base de tanino, que estimula a formação de pequenos focos com os sólidos que estão dissolvidos na água, acelerando sua decantação. O uso do coagulante acelera a clarificação da água e permite que ela siga o processo de tratamento convencional realizado pelo Serviço Autônomo de Água e Esgoto -SAAE(SAMARCO, DOSSIÊ, 2016a).

Estudos Geográficos, Rio Claro, 17(1): 6-31, jan./jun. $2019 \quad$ (ISSN $1678-698 X)$ http://www.periodicos.rc.biblioteca.unesp.br/index.php/estgeo
} 
Em relação à composição dos rejeitos minerários e aos possíveis danos à saúde, a Samarco afirmou desde os primeiros dias do rompimento que não eram tóxicos e não apresentavam riscos à saúde humana, nem ao meio ambiente. Adicionalmente, ela alegou que os metais presentes na água sempre estiveram no curso do Rio Doce e que, após tratamento, a água era considerada própria para consumo humano e seguia os parâmetros estabelecidos pela Portaria 2914/2011 da Agência Nacional de Vigilância Sanitária (ANVISA) (SAMARCO, DOSSIÊ, 2016a). No entanto, coletas e análises técnicas realizadas após o rompimento da barragem ao longo do Rio Doce, por órgãos públicos e grupos de pesquisa independentes, revelaram o contrário.

O Instituto Brasileiro do Meio Ambiente e dos Recursos Naturais Renováveis (IBAMA) e a Fundação S.O.S Mata Atlântica detectaram alterações e elevações de metais como alumínio, bário, cálcio, chumbo, cobalto, cobre, cromo, estanho, ferro, magnésio, manganês, níquel, potássio e sódio (IBAMA, 2015; S.O.S MATA ATLÂNTICA, 2016). Outras análises executadas pelo Grupo Independente de Avaliação do Impacto Ambiental (GIAIA) descobriram que o rio Gualaxo contava, em dezembro de 2015, com percentuais acima do permitido para: arsênio (cerca de duas vezes), cádmio (cerca de cinco vezes), manganês (cerca de quatro vezes), selênio (cerca de 16 vezes) e níquel (limítrofe, ou seja, no limite permitido). No mesmo período, o Rio Doce, em todos os pontos de coleta, apresentava ferro e alumínio dissolvidos em concentrações extremamente altas, em desconformidade com os valores estabelecidos pela Resolução 357, de 2005, do Conselho Nacional do Meio Ambiente (CONAMA). Os metais pesados - arsênio, cádmio, chumbo, crômio e níquel - também tiveram suas concentrações amplificadas em pontos alternados ao longo de toda a bacia hidrográfica (GIAIA, 2016).

A equipe da Fundação SOS Mata Atlântica também constatou no Rio Doce turbidez e totais de sólidos em suspensão em concentrações muito acima das permitidas pela legislação. Acrescente-se ainda que o Índice de Qualidade da Água (IQA) era péssimo; logo, a água era imprópria para o consumo humano e dessendatação animal em todo o trecho analisado (S.O.S MATA ATLÂNTICA, 2016). Apesar das análises e dos possíveis efeitos para a saúde no curto e médio prazos, a captação e distribuição de água do Rio Doce foi sendo restabelecida gradativamente e as pessoas ao longo da Bacia somaram a seu dia a dia novos riscos, incertezas e dúvidas. As perdas, danos e prejuízos econômicos, entretanto, não se restringiram apenas à qualidade da água. A passagem da lama também gerou outros impactos, entre eles: perda de áreas agrícolas e pastos; interrupção de geração de energia elétrica; destruição de áreas de preservação permanente (APP) e de vegetação nativa de Mata Atlântica; mortandade da fauna aquática e terrestre; assoreamento de cursos d'água; interrupção da pesca; interrupção do turismo e sensação de perigo e desamparo na população (IBAMA, 2015).

A população que habita os povoados, municípios e cidades banhados pelos rios atingidos e nas áreas estuárias e costeiras é constituída por agricultores familiares, camponeses, faiscadores, areeiros, quilombolas, assentados rurais, povos indígenas, ribeirinhos, pescadores artesanais, limpadores e catadores de caranguejos, artesãos, surfistas, vendedores, além dos moradores de pequenas e médias cidades. Destituídas de suas formas de subsistência pela destruição de lavouras e pastos e/ou em função da Estudos Geográficos, Rio Claro, 17(1): 6-31, jan./jun. 2019 (ISSN 1678—698X) http://www.periodicos.rc.biblioteca.unesp.br/index.php/estgeo 
contaminação do rio e do mar, essas pessoas ficaram sem alternativa para seu próprio sustento e sem perspectiva de retomada de suas vidas (IBAMA, 2015). As perdas e danos sofridos são, portanto, imensuráveis e de difícil quantificação.

O caso mais dramático e emblemático é o do povo Krenak ou Borun, que sofreu impactos materiais e imateriais incalculáveis, segundo o relatório elaborado pela equipe da Fundação Nacional do Índio (FUNAI, 2015). Depois de uma semana sem água, o caos generalizado tomou conta das sete aldeias que integram a terra indígena. Em protesto, os Krenak fecharam a Estrada de Ferro Vitória-Minas (que transporta vagões com minério de ferro para o porto de Tubarão, no Espírito Santo), pertencente à Vale, e exigiram soluções para seu drama: "Destruíram nossa vida, arrasaram nossa cultura, e nos ignoram. Não aceitamos", declarou uma liderança durante o ato (KAWAGUTI, SENRA, 2015b). Situação semelhante foi vivenciada por outros dois povos indígenas: os Tupiniquins e os Guaranis, no estado do Espírito Santo. Eles se viram obrigados também a paralisar a estrada de ferro da Vale, para exigir e garantir ações emergenciais para seu povo (ISA, 2016). Da mesma maneira que os Krenak, a lama tóxica prejudicou substancialmente a manutenção e reprodução dos seus modos de vida, com agravamento inclusive de problemas de saúde.

A chegada da lama na foz do Rio Doce também atingiu drasticamente moradores de vilas, agricultores familiares e pescadores artesanais que dependiam do rio e do mar para a sobrevivência de suas famílias (LEONARDO et al., 2017). Em função dos impactos ambientais e sociais provenientes da chegada da lama na foz, a Samarco foi obrigada pela Justiça Federal (JF) do Espírito Santo a efetuar ações emergenciais para facilitar o escoamento da lama ao mar (UOL Notícias, 2015). A primeira medida consistiu na abertura da foz do Rio Doce para evitar o represamento da lama na região e aumentar a vazão até o oceano; a segunda se ateve à instalação de boias infláveis para conter a contaminação da água por rejeitos em áreas sensíveis como mangues e ilhas. Essa foi a primeira vez que tais boias, similares às usadas em acidentes com vazamentos de petróleo, foram usadas em vazamento de rejeitos de mineração. No entanto, as ações emergenciais mostraram-se ineficazes (LEONARDO et al., 2017). A lama atingiu os mangues e demais áreas naturais e continuou se espalhando rapidamente mar adentro, afetando também ecossistemas estuarinos e marinhos do Espírito Santo e do Sul da Bahia (UFES, 2017).

Com o intuito de diminuir os danos à fauna, na região de Regência (ES), berçário de diversas espécies marinhas, em especial tartarugas, os integrantes do projeto TAMAR, com o apoio da Samarco, deslocaram, como medida preventiva, ninhos de tartarugas da rota da lama. No dia 21 de novembro de 2015, a lama finalmente encontrou o mar. Nesse dia, moradores e pescadores da vila de Regência, no município de Linhares (ES), fizeram um protesto. Vestidos com túnicas negras e munidos de cruzes, faixas, e com uma foice com o nome da Samarco, os moradores denunciaram a mineradora e suas controladoras pelas perdas e danos sociais e ambientais causados ao longo do Rio Doce.

Com a chegada da pluma de rejeitos, o rio tornou-se alaranjado e a água do mar ficou dividida em duas colorações (Figura 2). A agricultura em pequena escala, a pesca artesanal, a navegação, o comércio, o turismo, o surfe e o lazer dos moradores de Regência e das demais comunidades moradoras ao norte e ao sul da foz do Rio Doce ficaram inviabilizados e continuam assim até hoje (GREENPEACE, 2017). A Estudos Geográficos, Rio Claro, 17(1): 6-31, jan./jun. $2019 \quad$ (ISSN 1678-698X) http://www.periodicos.rc.biblioteca.unesp.br/index.php/estgeo 
pesca artesanal, principal fonte de subsistência e renda para as famílias, foi proibida legalmente por tempo indeterminado logo depois da chegada da pluma de rejeitos. Apesar de a Samarco garantir o abastecimento de água potável (e não de água mineral) em caminhões-pipa e poços artesianos, os moradores reclamam do cheiro, cor e gosto da água e convivem com dúvidas em relação à qualidade da água que chega às suas residências (LEONARDO et al., 2017). Em função da morosidade e da ausência de soluções imediatas e emergenciais para eliminar, aliviar ou minimizar os danos, essa crise aguda tornou-se crônica e perdura até hoje.

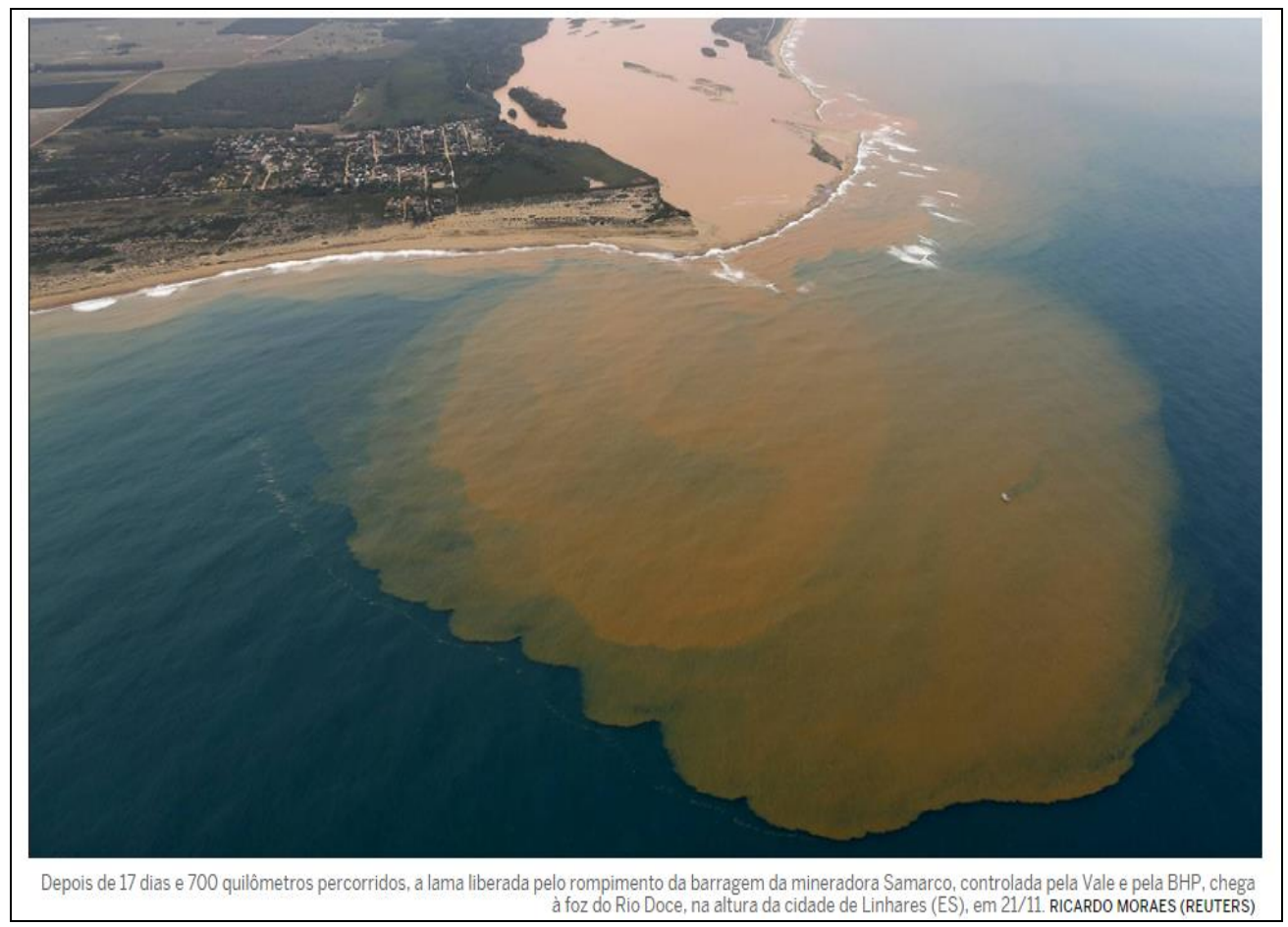

Figura 2 - A nova coloração da foz do Rio Doce.

Fonte: MENDONÇA (2015)

\section{VIOLÊNCIAS E VIOLAÇÕES SISTEMÁTICAS QUE SE RENOVAM: DA CRISE AGUDA À CRISE CRÔNICA}

A consultoria de gestão de riscos americana Bowker Associates classificou o rompimento de Fundão como o maior da história da mineração mundial nos últimos 100 anos, em virtude do volume de rejeitos despejados no meio ambiente, da distância percorrida pela lama e do investimento necessário para reparar as perdas ocasionadas pelo desastre (OLIVEIRA, 2016). O rompimento de Fundão, contudo, não é um acontecimento isolado ou excepcional na história da mineração. Pesquisa efetuada pelos americanos Lindsay Bowker e David Chambers (2015) sobre colapsos de barragens de rejeitos no mundo nos últimos 100 anos revela que, nas duas últimas décadas, os rompimentos vêm diminuindo em virtude do avanço tecnológico. Entretanto, apesar da redução, os rompimentos mais recentes têm ampliado sua magnitude, sendo classificados como graves ou muitos graves; isto é, os danos e Estudos Geográficos, Rio Claro, 17(1): 6-31, jan./jun. 2019 (ISSN 1678—698X) http://www.periodicos.rc.biblioteca.unesp.br/index.php/estgeo 
perdas humanas, sociais e ambientais têm sido muito maiores e irreparáveis. O colapso das barragens de rejeitos B-I, B-IV, B-IVA da Mina Córrego do Feijão, em 25 de janeiro de 2019, no município de Brumadinho/MG, deixou 308 vítimas (102 ainda desaparecidas) ${ }^{11}$ e contaminou o Rio Paraopeba. Ele lamentavelmente se processa como mais um exemplo ilustrativo dos graves danos/perdas socioeconômicos e socioambientais causados por essas explorações, suas plantas de operação e equipamentos.

As barragens, atualmente as maiores estruturas criadas pelo homem no planeta, têm tido um alto e crescente potencial de destruição. Elas são uma ameaça para diversas comunidades em virtude de sua localização - sempre a montante de comunidades -, a forma de construção, ampliação do barramento por alteamento ou a desativação sem fiscalização acurada. Esses reservatórios de lixo tóxico representam um risco socialmente fabricado e institucionalmente estruturado (GONÇALVES et al., 2009).No último terço do século $X X$, pesquisadores americanos estimam que seu potencial de risco aumentou em 20\% (BOWKER \& CHAMBERS, 2015). Chambers projeta uma média de um rompimento grave por ano no período de uma década, e, por essas razões, o colapso da barragem de Fundão não surpreendeu o pesquisador americano (LUCENA, 2015).

O mesmo não se pode dizer dos milhares de moradores que viviam à jusante da barragem, que desconheciam/desconhecem os riscos exponenciais que essas estruturas representam para suas vidas e para o meio ambiente. Diante da maior tragédia mundial da mineração, o mínimo que se poderia esperar, por parte das empresas responsáveis e do poder público, eram respostas emergenciais à altura da complexidade e magnitude dos danos. Contudo, não foi isso o que aconteceu.

Os dados coletados revelam que, em função da ineficácia e precariedade das respostas mobilizadas para enfrentar a crise aguda, as vidas dos moradores dos municípios banhados pelos rios Carmo, Gualaxo do Norte e Doce e pelo mar tornaramse ainda mais incertas e vulneráveis nos dias e meses posteriores ao rompimento da barragem e à passagem da lama. De maneira similar ao ocorrido no dia do rompimento da barragem, no período emergencial, as respostas corporativas e do poder público não estiveram à altura da magnitude, heterogeneidade e complexidade dos danos e perdas sofridos. Pelo contrário, as respostas mobilizadas, pífias e insuficientes, acirraram ainda mais as perdas e danos ao longo da Bacia, gerando um processo de sofrimento social coletivo, multidimensional e multifacetado (VALENCIO, 2016), que é vivenciado até hoje. Kleinman, Das e Lock (1997 apud ORTEGA, 2008) definem o sofrimento social como "o entrelaçamento de problemas humanos que têm suas origens e consequências nas feridas devastadoras que forças sociais infligem na experiência humana". Logo, o sofrimento social envolve diversas dimensões da experiência humana, incluídas a saúde, moral, religião, legalidade e bem-estar. Ele é resultante daquilo que "os poderes políticos, econômicos e institucionais fazem às pessoas e, reciprocamente, de como estas mesmas formas de poder influenciam as respostas aos problemas sociais" (ORTEGA, 2008, p. 26).

\footnotetext{
${ }^{11}$ Informações divulgadas pela Defesa Civil de Minas Gerais em 17/03/2019. Disponível em: https://bit.ly/2Cs8gCV. Acesso em 19 mar. 2019.

Estudos Geográficos, Rio Claro, 17(1): 6-31, jan./jun. $2019 \quad$ (ISSN $1678-698 X)$ http://www.periodicos.rc.biblioteca.unesp.br/index.php/estgeo
} 
A análise minuciosa das ações adotadas pelas empresas responsáveis, para enfrentar e/ou minimizar o evento em si durante o período emergencial, revela que elas propiciaram um cenário fértil de sofrimento coletivo sem precedentes na história recente do Brasil. Em Mariana (MG), município mais afetado, tanto a lentidão das respostas emergenciais quanto as omissões sistemáticas acarretaram incertezas e sofrimentos multidimensionais (físicos, psíquicos, emocionais) em diversos níveis e intensidades. Além das perdas e danos materiais e afetivos, as famílias vivenciaram processos angustiantes e humilhantes, como a ausência de informações sobre parentes mortos; 0 desconforto de terem que ir para hotéis e pousadas, muitos deles afastados do centro da cidade; a espera pela realocação em casas temporárias; a padronização e precarização da alimentação servida; e o preconceito/hostilidade após chegarem à cidade de Mariana. Os atingidos foram acusados, pelos demais moradores, de serem responsáveis pela interrupção das atividades da Samarco e/ou perda de empregos dos funcionários e pela redução de recolhimento dos royalties para a Prefeitura. Apesar da incessante reiteração da Samarco quanto à mobilização de "todos os recursos financeiros e humanos" e "as melhores condições para acolher as pessoas afetadas pela "tragédia" "12, a experiência vivida pelos mais de 600 moradores alocados em hotéis e pousadas contradiz tais afirmações.

Aliás, a Samarco (Vale/BHP) somente realocou em casas temporárias as famílias que perderam suas residências após pressão exercida por movimentos sociais e, em especial, como resultado da atuação judicial e extrajudicial da $2^{a}$ Promotoria de Justiça da Comarca de Mariana. As medidas judiciais garantiram, entre outros, direitos como o recebimento de auxílio financeiro mensal, a antecipação do pagamento de indenizações, o ressarcimento de vale-transporte para os servidores e professores de Bento Rodrigues, a garantia de acesso e segurança em Bento Rodrigues, 0 ressarcimento da diferença nas contas de energia, a contratação de assistência técnica, a anulação de contratos de compra e venda de animais, a garantia de atendimento psicossocial e a baixa nos veículos destruídos (ROJAS, PEREIRA, 2017).

Tais ações remetem a uma inversão clara entre direitos e concessões. Diferentemente dos direitos, que são coletivos e historicamente conquistados, as concessões costumam ser individuais, temporárias e parciais. Desse modo, quem as concede (as empresas) tem a prerrogativa de retirar as concessões quando julgar necessário. O entendimento de direitos como concessões, por parte das famílias atingidas, decorre de uma história de submissão e dominação - quando qualquer iniciativa por parte dos dominantes representa um avanço notável para quem só teria acesso a migalhas. Assim, a inversão entre direitos e concessões retarda e bloqueia a emergência de uma sociedade democrática fundada na criação, no reconhecimento, na garantia e consolidação de direitos (CHAUI, 1994). No caso em questão, observa-se que tais ações não transformaram verdadeira e estruturalmente as condições de vida das famílias de Mariana e sim reiteraram a política do silêncio (DEL GAUDIO et al., 2015, p.105).

A prorrogação recorrente de prazos e a lentidão para realizar ações emergenciais, porém, não se restringiram exclusivamente ao município de Mariana, local mais atingido e midiatizado. Pelo contrário, essa lógica operativa, isto, é o modus

\footnotetext{
${ }^{12}$ Samarco, Nota de Imprensa (2016d); DEL GAUDIO et al. (2015, p.104).

Estudos Geográficos, Rio Claro, 17(1): 6-31, jan./jun. $2019 \quad$ (ISSN $1678-698 X)$ http://www.periodicos.rc.biblioteca.unesp.br/index.php/estgeo
} 
operandi da gestão empresarial do desastre, propagou-se ao longo da Bacia, como mostra a Tabela 1.

\section{Tabela 1 - Negligências e omissões das empresas nos seis meses pós- rompimento da barragem de Fundão - 08/11/2015 a 05/05/2016}

\begin{tabular}{|c|c|}
\hline DATA & NEGLIGÊNCIAS E OMISSÕES \\
\hline $08 / 11 / 15$ & $\begin{array}{l}\text { Promotoria de Justiça de Mariana envia Recomendação à Samarco para o cadastramento } \\
\text { dos atingidos, fornecimento de renda mensal e moradia adequada para as famílias de } \\
\text { Bento Rodrigues. }\end{array}$ \\
\hline \multirow[t]{2}{*}{$13 / 11 / 15$} & $\begin{array}{l}\text { Samarco envia para Governador Valadares (MG) o primeiro carregamento de água } \\
\text { destinada ao consumo humano. A água continha altos teores de querosene. }\end{array}$ \\
\hline & $\begin{array}{l}\text { Samarco não apresenta Plano de Socorro às famílias atingidas conforme decretado pela } \\
\text { Justiça. }\end{array}$ \\
\hline $15 / 11 / 15$ & $\begin{array}{l}\text { Índios Krenak fecham a ferrovia Vitória-Minas, da Vale, em protesto contra a morte do rio } \\
\text { Doce, um rio sagrado para eles. }\end{array}$ \\
\hline $19 / 11 / 15$ & Galiléia (MG) enfrenta surto de diarreia e vômito por falta de água tratada. \\
\hline $20 / 11 / 15$ & Familiares realizam protesto e solicitam informações sobre os parentes desaparecidos. \\
\hline $24 / 11 / 15$ & Moradores de Colatina (ES) protestam em razão da má distribuição da água. \\
\hline \multirow[b]{2}{*}{$25 / 11 / 15$} & $\begin{array}{l}\text { Samarco é criticada pela ONU por demorar mais de três semanas para divulgar } \\
\text { informações sobre os riscos tóxicos da catástrofe. }\end{array}$ \\
\hline & $\begin{array}{l}\text { Vence o prazo para a empresa criar um fundo de } R \$ 1 \text { bilhão para ajuda às vítimas. } A \\
\text { empresa cria o fundo de forma incompleta, depositando apenas } \$ 200 \text { milhões, ou seja, } \\
25 \% \text { do total exigido. }\end{array}$ \\
\hline \multirow[b]{2}{*}{$27 / 11 / 15$} & $\begin{array}{l}\text { Samarco não inicia o pagamento de auxílio financeiro as famílias conforme havia } \\
\text { anunciado. }\end{array}$ \\
\hline & $\begin{array}{l}\text { Diante do perigo iminente de novas rupturas, a Justiça Estadual determina que a Samarco } \\
\text { tome medidas de prevenção para evitar possível rompimento das barragens de Santarém e } \\
\text { Germano. }\end{array}$ \\
\hline $29 / 11 / 15$ & Atingidos de Colatina (ES) interditam a BR-259 por falta de água. \\
\hline \multirow[b]{2}{*}{$01 / 12 / 15$} & $\begin{array}{l}\text { Moradores de Governador Valadares (MG) fecham a BR-116, para cobrar da Samarco a } \\
\text { distribuição de água potável. }\end{array}$ \\
\hline & $\begin{array}{l}\text { Atingidos pressionam a Samarco para agilizar a mudança das famílias desabrigadas dos } \\
\text { hotéis para casas alugadas. }\end{array}$ \\
\hline $02 / 12 / 15$ & $\begin{array}{l}\text { Samarco não entrega o Plano de Revisão de Cenário para Santarém e Germano, conforme } \\
\text { determinado pela Justiça Estadual. }\end{array}$ \\
\hline $04 / 12 / 15$ & $\begin{array}{l}\text { Samarco descumpre o prazo de entrega dos Planos de Emergência relativos a Santarém e } \\
\text { Germano. }\end{array}$ \\
\hline $09 / 12 / 15$ & Samarco se nega a firmar TAC proposto pelo Ministério Público Estadual de Mariana (MG). \\
\hline $11 / 12 / 15$ & $\begin{array}{l}\text { Samarco inicia pagamento de auxílio financeiro às famílias dos povoados destruídos. } \\
\text { Porém, só } 50 \text { famílias recebem o auxílio. A maioria das famílias atingidas não foi } \\
\text { cadastrada pela empresa. }\end{array}$ \\
\hline $14 / 12 / 15$ & $\begin{array}{l}\text { Samarco barra participação de moradores de Mascarenhas e Baixo Guandu (ES) numa } \\
\text { reunião, deflagrando protesto desses moradores. }\end{array}$ \\
\hline $15 / 12 / 15$ & A empresa adia o prazo de entrega do Plano Emergencial relativo às outras barragens. \\
\hline $17 / 12 / 15$ & $\begin{array}{l}\text { Moradores de Barra Longa (MG) reclamam que a Samarco cria dificuldades em seu } \\
\text { cadastramento. }\end{array}$ \\
\hline $18 / 12 / 15$ & $\begin{array}{l}\text { Samarco é obrigada a fornecer novamente água potável para os moradores de Governador } \\
\text { Valadares (MG), após análise da água mostrando concentração elevada de metais. }\end{array}$ \\
\hline $11 / 01 / 16$ & Samarco não entrega o Plano Emergencial das barragens Germano e Santarém. \\
\hline $12 / 01 / 16$ & Samarco entrega o Plano Emergencial incompleto, sem especificar medidas emergen \\
\hline
\end{tabular}

http://www.periodicos.rc.biblioteca.unesp.br/index.php/estgeo 


\begin{tabular}{|c|c|}
\hline & rmano $\mathrm{e}$ \\
\hline \multirow{3}{*}{$13 / 01 / 16$} & $\begin{array}{l}\text { Prefeitos de } 10 \text { municípios atingidos relatam dificuldades para conseguir da empresa ações } \\
\text { definitivas de recuperação de danos. }\end{array}$ \\
\hline & $\begin{array}{l}\text { Índios Tupinikim e Guarani (ES) ocupam trecho da ferrovia Vitória-Minas, operada pela } \\
\text { Vale, e cobram providências quanto à descontaminação do mar e do rio. }\end{array}$ \\
\hline & Vence o prazo para indenização das famílias que tiveram seus parentes mortos. \\
\hline \multirow{3}{*}{$28 / 01 / 16$} & $\begin{array}{l}\text { Índios Tupinikim e Guarani (ES) ocupam novamente a ferrovia da Vale em protesto à } \\
\text { negativa da empresa de compensá-los pelos impactos da lama. }\end{array}$ \\
\hline & $\begin{array}{l}\text { Moradores de Cachoeira Escura (MG) ocupam as ruas da cidade para reivindicar direito de } \\
\text { acesso à água. }\end{array}$ \\
\hline & $\begin{array}{l}\text { Samarco entrega o Plano de recuperação do Rio Doce, que é avaliado pelo IBAMA como } \\
\text { genérico e superficial. }\end{array}$ \\
\hline $04 / 02 / 16$ & $\begin{array}{l}\text { İndios Tupinikim e Guarani (ES) bloqueiam rodovias em Aracruz em protesto contra o } \\
\text { descaso das empresas. }\end{array}$ \\
\hline $12 / 02 / 16$ & $\begin{array}{l}\text { Em reunião, empresas negam responsabilidade por impactos nas Terras Indígenas } \\
\text { Tupiniquim e Guarani (ES). }\end{array}$ \\
\hline $13 / 02 / 16$ & $\begin{array}{l}\text { Moradores de Barra Longa (MG) reclamam do barulho, poeira e infestação de ratos no } \\
\text { distrito. }\end{array}$ \\
\hline $20 / 02 / 16$ & $\begin{array}{l}\text { Atingidos ocupam a linha férrea da Vale, no município de Tumiritinga (MG), para exigir a } \\
\text { continuação do abastecimento de água mineral na região e cadastramento das famílias. }\end{array}$ \\
\hline $29 / 02 / 16$ & $\begin{array}{l}\text { Índios Tupinikim e Guarani (ES) voltam a bloquear a ferrovia da Vale em protesto contra a } \\
\text { negativa da empresa de reconhecer os impactos da lama nas terras indígenas. }\end{array}$ \\
\hline $01 / 03 / 16$ & $\begin{array}{l}\text { Moradores de Barra Longa (MG) protestam contra o surto de dengue provocado pela lama } \\
\text { do rejeito despejado pela Samarco. }\end{array}$ \\
\hline $08 / 03 / 16$ & $\begin{array}{l}\text { Atingidos de Cachoeira Escura (MG) ocupam linha férrea da Vale em protesto contra as } \\
\text { ações da Samarco. }\end{array}$ \\
\hline $11 / 03 / 16$ & $\begin{array}{l}\text { Atingidos ocupam linha férrea por } 35 \text { horas e conquistam reunião com a Samarco, Vale e } \\
\text { com o Governo de Minas. }\end{array}$ \\
\hline $16 / 03 / 16$ & $\begin{array}{l}\text { Samarco ignora reivindicações de atingidos e do Ministério Público em reunião de } \\
\text { negociação realizada em Barra Longa (MG). }\end{array}$ \\
\hline $11 / 04 / 16$ & $\begin{array}{l}\text { Pescadores de Vitória (ES) e de Conceição da Barra (ES) fazem novos protestos contra os } \\
\text { prejuízos gerados pela Samarco. }\end{array}$ \\
\hline $12 / 04 / 16$ & $\begin{array}{l}\text { Atingidos de Aimorés (MG) ocupam linha férrea da Vale e pedem ações concretas das } \\
\text { empresas. }\end{array}$ \\
\hline $29 / 04 / 16$ & Moradores bloqueiam entrada de Regência (ES) e pedem distribuição de água potável. \\
\hline $03 / 05 / 16$ & $\begin{array}{l}\text { Justiça obriga Samarco/Vale-BHP a manter abastecimento de água potável em Regência } \\
\text { (ES). }\end{array}$ \\
\hline 05/05/16 & $\begin{array}{l}\text { Seis meses após o desastre, muitas famílias atingidas ainda não foram cadastradas, nem } \\
\text { receberam auxílio financeiro. }\end{array}$ \\
\hline $05 / 05 / 16$ & $\begin{array}{l}\text { Seis meses após a ruptura da barragem, a empresa não conseguiu deter o vazamento de } \\
\text { rejeitos nos cursos d'água e no Rio Doce. }\end{array}$ \\
\hline
\end{tabular}

Fonte: ROJAS e PEREIRA (2017, pp. 8-9).

A tabela acima mostra os protestos, mobilizações e contestações que decorreram do sistemático descumprimento, por parte da empresa, nos seis meses após o desastre, das suas obrigações em relação às ações emergenciais, bem como dos prazos dados pela Justiça para sua execução. Entre as determinações judiciais descumpridas e/ou prorrogadas estão as de oferecer ajuda humanitária, entregar estudos e planos de emergência e de segurança, estabilizar as estruturas remanescentes e mitigar impactos ao meio ambiente, ao longo dos mais de $600 \mathrm{~km}$ afetados pela lama. Conforme se observa na tabela, a Samarco, somente em poucas

Estudos Geográficos, Rio Claro, 17(1): 6-31, jan./jun. $2019 \quad$ (ISSN 1678—698X) http://www.periodicos.rc.biblioteca.unesp.br/index.php/estgeo 
situações, de modo parcial e incompleto, cumpriu os acordos e as ações humanitárias, ambientais e de segurança.

Em função desses descasos recorrentes, a atuação da empresa foi avaliada como "extremamente morosa" e "pouco efetiva" pelo defensor público de Direitos Humanos, Vladmir Rodrigues (MANSUR, 2016). Os prefeitos dos municípios afetados também questionaram as ações emergenciais adotadas pela Samarco e exigiram maior determinação, agilidade e objetividade na resolução dos problemas (ALMG, 2016). Além disso, as empresas e o governo brasileiro foram criticados pela Organização das Nações Unidas (ONU). No final de visita realizada ao Brasil, o grupo de trabalho da entidade divulgou declaração afirmando que as respostas emergenciais eram inaceitáveis e as providências tomadas pelo governo brasileiro e pela Vale e BHP, claramente insuficientes. A declaração, divulgada oficialmente em 16 de dezembro de 2015, enfatizava que:

O Grupo de Trabalho notou que haviam se passado quase duas semanas até que a empresa informasse o público de que outras duas estruturas (Santarém e Selinha) também apresentavam riscos. Da mesma maneira, a empresa não havia fornecido informações às comunidades sobre os riscos à saúde derivados da lama. Também houve uma clara falha no plano de contingência da empresa. As pessoas das comunidades afetadas alegam não ter sido alertadas sobre o desastre pela empresa ou pelas forças de defesa civil. Isso aconteceu apesar das cerca de 10 horas entre o rompimento da barragem e a inundação de Bento Rodrigues, o primeiro povoado a ser alagado. Um alerta antecipado teria permitido que as pessoas retirassem alguns de seus pertences e poderia ter salvado vidas, como nota a ação civil impetrada em 9 de dezembro de 2015 pelo Ministério Público do Estado de Minas Gerais contra a Samarco, a Vale e a BHP. Em 11 de novembro de 2015, o Ministério Público de Minas Gerais buscou um acordo com a Samarco para garantir a soma de 300 milhões de reais (77 milhões de dólares americanos) para indenizar as vítimas. Apesar de várias tentativas de acordo, a Samarco não concordou, o que levou à submissão da ação civil.

E concluía que,

Devido à escala do desastre, o Grupo de Trabalho considera que as autoridades federais e estaduais precisam assumir um papel mais ativo na resposta ao desastre. Embora o Grupo de Trabalho tenha sido informado pela Presidência da República sobre as ações de assistência emergencial, o Governo precisa fornecer informações mais claras à população, bem como orientações sobre o processo de reassentamento e a definição da compensação. Embora a Samarco seja responsável por reparar os danos causados, o Estado permanece o principal garantidor do respeito aos direitos humanos das comunidades afetadas (ONU, 2015).

Estudos Geográficos, Rio Claro, 17(1): 6-31, jan./jun. $2019 \quad$ (ISSN 1678—698X) http://www.periodicos.rc.biblioteca.unesp.br/index.php/estgeo 
Esse conjunto de precariedades e omissões no pós-impacto contribuíram para engendrar um desastre, isto é, um processo de sofrimento social coletivo multidimensional e multifacetado (VALENCIO, 2018) vivenciado até hoje. Produto de processos sociais territorialmente circunscritos e não de fenômenos naturais (VALENCIO, 2018, 2016, 2009; MARCHEZINI, 2009; SIENA, 2014), o desastre provoca uma ruptura súbita na rotina coletiva e desestabiliza estruturas e adaptações sociais (OLIVER-SMITH 1998 apud SIENA, 2014), como já salientamos. Oriundo de um evento físico perturbador, que provoca um estresse coletivo - como chuvas, terremotos, tsunamis, colapsos de barragens, etc. -, ele persevera enquanto durar o sofrimento coletivo, inflado por condições políticas, culturais, sociais, econômicas e psíquicas incongruentes impostas aos grupos afetados.

Algumas abordagens da sociologia crítica consideram o desastre como uma crise eminentemente social, que envolve tanto a esfera privada como a esfera pública de uma determinada coletividade (VALENCIO, 2013). Assim, o desastre diz respeito a uma crise que abrange desde o plano intersubjetivo até o plano político-institucional (Ibid, 2013). Nesse contexto, os agentes destrutivos devem ser compreendidos "não como causa do desastre, mas sim como prenúncio de uma crise" (QUARANTELLI, 1998 apud MARCHEZINI, 2009, p. 49). Vale relembrar que a existência de uma crise pressupõe pelo menos três aspectos: 1) a manifestação de um evento ameaçante, neste caso, o rompimento da barragem; 2) um ambiente de grande incerteza decorrente da natureza da ameaça e de suas consequências potenciais, diante das quais é necessário acionar respostas imediatas; e, 3) um nível de exposição e grau de vulnerabilidade acentuado, que coloca as autoridades na urgência de agir, tanto para contê-las quanto para evitar seus desdobramentos (VALENCIO, 2018). Portanto, quando as ações são insuficientes para evitar os desdobramentos e diminuir ou evitar a vivência do sofrimento coletivo, a crise inicialmente aguda torna-se crônica (VALENCIO, 2016; ZHOURI et al., 2016b). Nesse contexto, violências materiais e simbólicas e violações de direitos humanos proliferam e tornam-se cotidianas, conforme denunciam os afetados ao longo da Bacia do Rio Doce nos últimos três anos.

\section{CONCLUSÕES}

"Toda a história do petróleo [e da mineração] está repleta de criminalidade, corrupção, o exercício grosseiro do poder e o pior do capitalismo de fronteira". Michael J. Watts (1999) [inclusão nossa]

Conforme demostrado, as investigações efetuadas pelas polícias e Ministérios Públicos evidenciaram que os executivos da Vale S.A. e da BHP Billiton participavam das reuniões e dos Conselhos da Samarco e tinham pleno conhecimento das falhas, dos problemas e das "não conformidades" da represa, ou seja, da probabilidade de ocorrência de uma tragédia. A partir dessas informações, em 20 de outubro de 2016, 0 MPF apresentou uma denúncia perante a Justiça Federal em Ponte Nova (MG), acusando 22 pessoas físicas, 21 delas por crime de homicídio qualificado com dolo eventual (quando se assume o risco de matar). Essas mesmas pessoas físicas, Estudos Geográficos, Rio Claro, 17(1): 6-31, jan./jun. 2019 (ISSN 1678—698X) http://www.periodicos.rc.biblioteca.unesp.br/index.php/estgeo 
juntamente com quatro pessoas jurídicas - Samarco Mineração S.A., Vale S.A., BHP Billiton Brasil LTDA e VogBR Recursos Hídricos e Geotecnia LTDA -, foram também acusadas de crimes ambientais (MPF, 2016). Ou seja, além de responderem pelo crime de homicídio qualificado (Art. 121, parágrafo $2^{\circ}$ ), os denunciados foram igualmente acusados de outros três crimes previstos no Código Penal: inundação (Art. 254), desabamento/desmoronamento (Art. 256) e lesão corporal (Art. 129). Adicionalmente, as 21 pessoas ainda foram denunciadas por quatro crimes previstos na legislação ambiental (Lei n. ${ }^{0}$ 9.605/98): poluição qualificada (Art. 54) e crimes contra a fauna (Art. 29), contra a flora (Art. 38, 40, 49, 50), contra o ordenamento urbano e o patrimônio cultural (Art. 62) e contra a administração ambiental (Art. 68, 69) (MPF, 2016).

Contudo, passados três anos após o rompimento da barragem, nenhum dos 22 acusados foi sequer pronunciado (pronúncia é a fase do processo penal em que o juiz decide se os acusados de homicídio serão submetidos a júri popular). Além disso, recentes decisões do Tribunal Regional Federal da 1a Região (TRF-1), órgão de segunda instância da Justiça Federal de Minas Gerais, parecem indicar que a ação penal contra os executivos pode vir a ser progressivamente aniquilada: em 09/10/2018, o TRF-1 concedeu habeas corpus a um executivo da Samarco ligado à Vale (José Carlos Martins), trancando inteiramente a ação penal em relação a ele, razão pela qual ele foi excluído do processo. No mesmo dia 09, o mesmo tribunal concedeu também habeas corpus a Andre Ferreira Gavinho Cardoso, executivo da Samarco ligado à anglo-australiana BHP, para excluir da acusação os crimes de homicídio e lesões corporais, o que, na prática, cria um precedente jurisprudencial, que pode favorecer outros réus que requeiram a mesma medida.

No segundo momento, isto é, no pós-impacto, mostramos que as respostas imediatas das empresas não estiveram à altura dos danos e perdas iniciais. Em outras palavras, o enfrentamento da crise aguda ficou aquém do esperado. Apesar de vários grupos sociais terem sido expostos a um evento ameaçante, o que gerou e continua promovendo grandes incertezas, eles foram/são submetidos a um nível de exposição e a um grau de vulnerabilidade acentuados, similares ao experimentado no pré-impacto.

Por último, num terceiro momento, constatamos que diante da ineficiência das providências adotadas pelas empresas e pelo poder público para evitar 0 desdobramento de danos e prejuízos, os grupos afetados passaram a vivenciar uma sucessão de crises sociais pontuais (ex: ausência de informações, moradias e cotidianos; lacunas quanto às decisões que afetam seu futuro; falta de água; proliferação de epidemias; ocorrência de doenças psíquicas e físicas; constrangimentos corriqueiros, etc.). As sucessivas crises específicas têm evoluído para uma crise crônica sem perspectiva clara de solução. Esse processo de vulnerabilização acentuado, socialmente construído e decorrente de práticas político-institucionais (ACSELRAD, 2006) negligentes, fez emergir um cenário catastrófico ao longo da Bacia do Doce. Perdas e danos sociais e ambientais incomensuráveis - e ainda não identificados e quantificados - permanecem na ordem do dia, embora, com o passar do tempo, estejam esmaecendo no imaginário da população.

Os três momentos analisados revelam que o (neo)extrativismo é uma modalidade de acumulação essencialmente depredadora: uma modalidade que engendra processos que atropelam, espoliam e destroem vidas, culturas, territórios, direitos, instituições democráticas, entre outros (ROJAS, PEREIRA, DIAS, 2018; Estudos Geográficos, Rio Claro, 17(1): 6-31, jan./jun. 2019 (ISSN 1678—698X) http://www.periodicos.rc.biblioteca.unesp.br/index.php/estgeo 
GUDYNAS, 2018). Esse modelo mantém e reproduz os rasgos e contradições estruturantes do extrativismo do período colonial (ACOSTA, 2011). Trata-se de um extrativismo primário-exportador submetido e subordinado às demandas globais, que não altera as diferenças e iniquidades na distribuição da riqueza local e gera processos violentos, repressivos e autoritários. Uma modalidade de acumulação que opera entre a legalidade e a ilegalidade, com altas doses de impunidade e que redefine e reduz 0 conceito de Justiça (GUDYNAS, 2018, 2015; ACOSTA, 2011).

As múltiplas violências ou "extrahecciones", isto é, aquilo que é arrancado com violência (GUDYNAS, 2018), manifesta-se no plano físico, simbólico, epistemológico, econômico, cultural, social, etc. O leque de violências e violações é amplo e se espalha no tempo e no espaço. De Mariana (MG) a Regência (ES), a exposição e o grau de vulnerabilidade dilatam-se e as incertezas afloram e proliferam com o passar dos meses e anos, principalmente no que concerne à localização e condições de reconstrução dos povoados, à duração dos auxílios emergenciais, ao reconhecimento como afetados, à qualidade da água e do pescado, às indenizações oferecidas ou que ainda não chegaram, aos mecanismos de participação propostos, à criminalização dos protestos, à possibilidade de algum dia os atingidos recuperarem as atividades econômicas e os modos de vida que perderam com a passagem da lama (ROJAS, PEREIRA, 2017; MILANEZ, LOSEKANN, 2016). A crise crônica revela-se de maneira multidimensional e multifacetada. Além do sofrimento social coletivo e da dificuldade para retornar e recuperar as rotinas diárias, os moradores experimentam problemas decorrentes do desequilíbrio ambiental, como surtos de diarreia, vômito, febre amarela, dengue e chickunguya. Acrescenta-se ainda os adoecimentos psíquicos, como quadros depressivos, transtornos de ansiedade generalizada, suicídios, problemas no sono, dores de cabeça crônicas, transtorno de estresse pós-traumático, transtorno por uso de substâncias e uso de medicamentos psicotrópicos, entre outros (DAS NEVES et al., 2018; ALEIXO et al., 2017; LEONARDO et al., 2017).

Assim, diante de tão diversos sofrimentos, dificuldades, violências e violações, como contabilizar e calcular valores financeiros para todos esses males, decorrentes do (neo)extrativismo, numa sociedade cada vez mais afeita à monetarização e mercantilização de tudo, de todos e da própria vida? Como poderíamos, junto com os minérios/commodities, exportar também essas violências e o sofrimento social?

\section{REFERÊNCIAS}

ACOSTA, A. La maldición de la violencia: Extractivismo al desnudo. Extractivismo.com, 2011. Disponível em: https://goo.gl/5PZqip. Acesso em: 05 nov. 2018.

ACSELRAD, H. Mariana, novembro de 2015: a genealogia política de um desastre. In: ZHOURI, A. (Org). Mineração, violências e resistências: um campo aberto à produção de conhecimento no Brasil. Marabá, PA: Editorial iGuana; ABA, 2018, p. 155175.

Estudos Geográficos, Rio Claro, 17(1): 6-31, jan./jun. 2019 (ISSN 1678—698X) http://www.periodicos.rc.biblioteca.unesp.br/index.php/estgeo 
- Vulnerabilidade Ambiental, processos e relações. Comunicação ao II Encontro Nacional de Produtores e Usuários de Informações Sociais, Econômicas e Territoriais, FIBGE; Rio de Janeiro, 2006.

ASSEMBLEIA LEGISLATIVA DE MINAS GERAIS - ALMG. Prefeituras e autoridades cobram agilidade da Samarco. Cobrança é para que reparações para os atingidos com rompimento da barragem sejam mais rápidas e concretas. 2016. Disponível em: https://goo.gl/Cxrtpv. Acesso em: 22 nov. 2017.

ALEIXO, L., DRUMMOND, A.; NICÁCIO, C. Direito das populações afetadas pelo rompimento da barragem de Fundão: povo Krenak. Relatório de atividades. Belo Horizonte: CDH/UFMG, 2017, Greenpeace.

BRAGA, F.; CELESTINO, G. Moradores de Colatina (ES) enfrentam fila para conseguir água. Folha de São Paulo, 2015. Disponível em: https://goo.gl/6eJgd5. Acesso em: 22 mar. 2018.

BOWKER, L.; CHAMBERS, D. The risk, public liability \& economics of tailings storage facility failures, 2015.

CARNEIRO, E. Atividades minerárias e conflitos ambientais e territoriais em Minas Gerais (Brasil): Trajetória histórica. In: ZHOURI, A.; BOLADOS, P.; CASTRO, E (Org). Mineração na América do Sul. Neoextrativismo e lutas territoriais. São Paulo: Annablume, 2016, p. 255-278.

CANTALAPIEDRA, S. Extractivismos, modo de vida imperial y violencia. Papeles de relaciones ecosociales y cambio global, n. 143, 2018, p. 5-11. Disponível em: https://goo.gl/BdrVWX. Acesso em: 22 jan. 2019.

CHAUÍ, M. Raízes teológicas do populismo no Brasil: teocracia dos dominantes, messianismo dos dominados. In: DAGNINO, E. (Org). Anos 90: política e sociedade no Brasil. São Paulo: Ed. Brasiliense, 1994.

DAS NEVES, M.; ROQUE, M.; FREITAS, A.; GARCIA, F. PRISMMA: Pesquisa sobre a saúde mental das famílias atingidas pelo rompimento da barragem do Fundão em Mariana. Belo Horizonte: Corpus, 2018.

DEL GAUDIO, R.; FREITAS, E. ; PEREIRA, D. Desenvolvimento sustentável e ideologia: interpelações. Lutas Sociais (PUCSP), v. 19, p. 99-111, 2015.

DEPARTAMENTO NACIONAL DE PESQUISA MINERAL - DNPM. Portaria $\mathbf{N}^{\circ} \mathbf{5 2 6}$ de 9 de dezembro de 2013. Disponível em: https://goo.gl/jqMucC. Acesso em: $04 \mathrm{dez}$. 2017.

Portaria $\mathbf{N}^{\circ} \mathbf{4 1 6}$ de $\mathbf{0 3}$ de Setembro de 2012. Disponível em: https://goo.gl/2mQehM. Acesso em: 04 dez. 2017.

Estudos Geográficos, Rio Claro, 17(1): 6-31, jan./jun. 2019 (ISSN 1678—698X) http://www.periodicos.rc.biblioteca.unesp.br/index.php/estgeo 
FUNDAÇÃO NACIONAL DO INDIO - FUNAI. Impactos causados pelo despejo de rejeitos oriundos do rompimento da barragem de Fundão/Samarco Mineração. Relatório Preliminar, 2015.

GABINETE MILITAR DO GOVERNADOR DO ESTADO DE MG - GMG. Relatório da gestão do desastre rompimento de barragem em Mariana/MG-Nov./2015. Belo Horizonte, 2015.

GONÇALVES, J. ; MARCHEZINI, V.; VALENCIO, N. Colapso de barragens: aspectos sócio-políticos da ineficiência da gestão dos desastres no Brasil. In: VALENCIO, N.; SIENA, M; MARCHEZINI, V.; GONÇALVES, J. (Org.). Sociologia dos Desastres: construção, interfaces e perspectivas no Brasil. 1ed. São Carlos: RiMa, v. 1, 2009, p. 160-175.

GREENPEACE. A extensão da tragédia da lama e da dor na Foz do Rio Doce. Disponível em: https://goo.gl/rH7E1U. Acesso em 06 jun.2017.

GRUPO INDEPENDENTE PARA AVALIAÇÃO DE IMPACTO AMBIENTAL - GIAIA. Determinação de metais na bacia do Rio Doce (Período: dezembro-2015 a abril2016). Relatório Técnico, 2016.

GUDYNAS, E. Extractivismos: el concepto, sus expresiones y sus múltiples violencias. Papeles de relaciones ecosociales y cambio global, n. 143, 2018, p. 61-70. Disponível em: https://goo.gl/zdKGCN. Acesso em: 22 jan. 2019.

. Extractivismos en América del Sur: conceptos y sus efectos derrame. In: ZHOURI, A.; BOLADOS, P.; CASTRO, E (Org). Mineração na América do Sul. Neoextrativismo e lutas territoriais. São Paulo: Annablume, 2016, p. 23-43.

Transições Pós-Estrativistas: superando o desenvolvimento e a exploração da natureza. Rio de Janeiro: Ed.lbase, Claes, Ford Foundation, 2012.

G1-ES. Exército fica no ES por mais uma semana a pedido de Hartung. 2015a. Disponível em: https://goo.gl/k1XZ6k. Acesso em: 02 fev. 2018.

HARVEY, D. El "nuevo" imperialismo: acumulación por desposesión. Buenos Aires: CLACSO, 2005. Disponível em: https://goo.gl/yZrNry. Acesso em: 12 dez 2016.

IBRAM. Royalty: mineradoras recolhem mais CFEM em 2018. 05/04/2018. Disponível em: https://goo.gl/Ra66mS Acesso 06 abr.2018.

INSTITUTO BRASILEIRO DO MEIO AMBIENTE E DOS RECURSOS NATURAIS Renováveis - IBAMA. Laudo Técnico Preliminar. Impactos ambientais decorrentes do desastre envolvendo o rompimento da barragem de Fundão, em Mariana, Minas Gerais, 2015.

Estudos Geográficos, Rio Claro, 17(1): 6-31, jan./jun. 2019 (ISSN 1678—698X) http://www.periodicos.rc.biblioteca.unesp.br/index.php/estgeo 
INSTITUTO SOCIOAMBIENTAL - ISA. Índios ocupam trilhos da Vale e cobram providências sobre contaminação do mar e rio. 2016. Disponível em: https://goo.gl/kpXDda. Acesso em: 03 maio 2018.

KAWAGUTI, L.; SENRA, R. Mineradora não entrega água suficiente para cidade afetada por lama, diz prefeita. G1-MG, 2015a. Disponível em: https://goo.gl/hGZZuu. Acesso em: 03 maio 2018.

. Índios fecham ferrovia da Vale em MG em protesto contra "morte de rio sagrado". BBC News - Brasil, 2015b. Disponível em: https://goo.gl/3LHzzL. Acesso em: 12 jul. 2018.

LEONARDO, F.; IZOTON, J. ; VALIM, H. CREADO, E. TRIGUEIRO, A. SILVA, B. DUARTE, L. SANTANA. N. Rompimento da barragem de Fundão (SAMARCO/VALE/BHP BILLITON) e os efeitos do desastre na foz do Rio Doce, distritos de Regência e Povoação, Linhares (ES). Relatório de pesquisa. GEPPEDES, 2017.

LUCENA, E. Tragédia da Samarco teve triplo recorde mundial, diz consultoria. Folha de São Paulo, 2015. Disponível em: https://goo.gl/7RnCzp. Acesso em: 02 fev. 2017.

MALERBA, J. ; MILANEZ, B.; WANDERLEY, L. Novo Marco Legal da Mineração no Brasil: Para quê? Para quem? Rio de Janeiro: Ed. FASE, 2012.

MANSUR, R. Prefeituras reclamam de lentidão da Samarco na recuperação dos danos. O Tempo, 2016. Disponível em: https://goo.gl/KUaF5X. Acesso em: 23 jun. 2018.

MARQUES, J. ; BERTONI, E. PF indicia integrante da Vale e mais sete pessoas por tragédia de Mariana. Folha de São Paulo, 2016. Disponível em: https://goo.gl/oQCsgH. Acesso em: 23 jun. 2018.

MARCHEZINI, V. Dos desastres da natureza à natureza dos desastres. In: VALENCIO, N.; SIENA, M; MARCHEZINI, V.; GONÇALVES, J. (Org.). Sociologia dos Desastres: construção, interfaces e perspectivas no Brasil. São Carlos: RiMa, 2009, v. 1, p. 48-57.

MENDONÇA, $\mathrm{H}$. $\mathrm{O}$ ano de inferno astral das gigantes brasileiras Petrobras e Vale. 19/12/2015. Disponível em: https://goo.gl/aV5hfY Acesso em: 03 jan. 2016.

MILANEZ, B.; LOSEKANN, C. Desastre no vale do Rio Doce: antecedentes, impactos e ações sobre a destruição. Rio de Janeiro: Ed. Folio Digital: Letra e imagem, 2016.

MINISTÉRIO PÚBLICO FEDERAL - MPF. Força Tarefa Rio Doce. Denúncia. 2016. Disponível em: https://goo.gl/7j3Xvt. Acesso em: 03 dez. 2017.

Estudos Geográficos, Rio Claro, 17(1): 6-31, jan./jun. 2019 (ISSN 1678—698X) http://www.periodicos.rc.biblioteca.unesp.br/index.php/estgeo 
MINISTÉRIO DO TRABALHO E PREVIDÊNCIA SOCIAL - MPTS. Relatório de Análise de acidente: Rompimento da barragem de rejeitos Fundão em Mariana-MG, 2016.

OLIVEIRA, N. Desastre em Mariana é o maior acidente mundial com barragens em 100 anos. Agência Brasil, 2016. Disponível em: https://goo.gl/Uu4dB5. Acesso em: 08 maio 2018.

ORGANIZAÇÃO DAS NAÇÕES UNIDAS - ONU. Declaração ao final da visita ao Brasil do Grupo de Trabalho das Nações Unidas sobre Empresas e Direitos Humanos. Brasília, 16 de dezembro de 2015. Disponível em: https://goo.gl/VDxj74. Acesso em: 05 maio 2018.

ORTEGA, F. Veena Das: sujetos del dolor, agentes de dignidade. Bogotá: Universidad Nacional de Colombia, Pontificia Universidad Javeriana, Instituto Pensar, 2008.

PETRAS, J. Brasil: o capitalismo extrativo e o grande salto para trás. Tensões Mundiais, Fortaleza, v. 10, n. 18, 19, 2014, pp. 301-323.

POLÍCIA CIVIL DE MINAS GERAIS - PCMG. Inquérito Policial № 712/2015, 2016.

POLÍTICA NACIONAL DE SEGURANÇA DE BARRAGENS. Lei No 12.334, de 20 de setembro de 2010. Disponível em: https://goo.gl/AfExuo. Acesso em: 04 dez. 2017.

ROJAS, C. Os conflitos ambientais na Serra do Gandarela na perspectiva das comunidades locais. Belo Horizonte. Dissertação (Mestrado em Geografia). Universidade Federal de Minas Gerais, 2014.

ROJAS, C.; PEREIRA, D. O rompimento da barragem de Fundão/MG: reflexões preliminares sobre o modus operandi da Samarco (Vale/BHP Billiton). Anais do $41^{\circ}$ Encontro Anual da ANPOCS, Caxambu, 2017. Disponível em: https://goo.gl/AtM4fY. Acesso em: 10 jan. 2018.

ROJAS, C.; PEREIRA, D.; DIAS, J. "Participação", "Resolução Negociada" de Conflitos e (Neo)extrativismo no Brasil: o Parque Nacional da Serra do Gandarela (MG/Brasil)". Revista de Estudios Andaluces, Sevilla, n. 36, 2018, 121-146. Disponível em: https://goo.gl/suzzzD. Acesso em: 02 ago. 2018.

SAMARCO. . DOSSIÉ SAMARCO, 11 DE JANEIRO 2016a. Fazer o que deve ser feito. Esse é o nosso compromisso. Disponível em: https://www.samarco.com. Acesso em: 20 fev. 2016.

BOOK SAMARCO. UM ANO DO ROMPIMENTO DE FUNDÃO, 2016b. Disponível em: https://goo.gl/7pzU1s. Acesso em: 24 maio 2017.

Estudos Geográficos, Rio Claro, 17(1): 6-31, jan./jun. 2019 (ISSN 1678—698X) http://www.periodicos.rc.biblioteca.unesp.br/index.php/estgeo 
Entenda o rompimento. 2016c. Disponível em: https://goo.gl/LjiDzT. Acesso em: 03 dez. 2017.

Nota de imprensa. Posicionamento da Samarco sobre denúncia do MPMG (05/05/2016). (2016d). Disponível em: https://goo.gl/LpLB1B Acesso em: 20 out. 2017.

Relatório da administração e demonstrações financeiras - 2014. Disponível em: https://goo.gl/2DgiFL. Acesso em: 22 jan. 2017.

SENRA, R. A mãe que sofreu aborto na lama e luta para incluir feto entre vítimas de Mariana. BBC Brasil, 2016. Disponível em: https://goo.gl/GnB5zg. Acesso em: 2 maio 2018.

SIENA, M. Desastres y vulnerabilidad: un debate que no puede parar. Bulletin de I'Institut français d'études andines, 2014, 43, (3), 8 dez, p. 433-443.

S.O.S MATA ATLÂNTICA. Laudo técnico parcial: expedição bacia do rio doce, 2016.

TEUBAL, M.; PALMISANO, T. Acumulación por desposesión: la colonialidad del poder en América Latina. In: MASSUH, G. Renunciar al bien común: extractivismo y (pos)desarrollo en América Latina. Buenos Aires: Mardulce, 2012, pp. 131-156.

UNIVERSIDADE FEDERAL DE ESPÍRITO SANTO - UFES. Monitoramento da Influência da Pluma do Rio Doce após o rompimento da Barragem de Rejeitos em Mariana/MG - Novembro de 2015: Processamento, Interpretação e Consolidação de Dados. Vitória, Centro de Ciências humanas e Naturais, Departamento de Oceanografia, 2017.

UOL Notícias. Justiça ordena que Samarco barre chegada da lama ao mar. 2015. Disponível em: https://goo.gl/nvmgJS. Acesso em: 08 fev. 2018.

VALENCIO, N. Da dinâmica institucional de decretação de emergências à dinâmica social de vivência dos desastres: repensando o teor das crises para incrementar as políticas de proteção civil (Palestra). UFMG, Fafich, 2018.

- Elementos constitutivos de um desastre catastrófico: os problemas científicos por detrás dos contextos críticos. Ciência \& Cultura, 2016, v. 68 n. 3 São Paulo July/Sep., pp. 41-45.

A crise social denominada Desastre: subsídios para uma rememoração coletiva acerca do foco principal do problema. In: VALENCIO, N. (Org). Sociologia dos desastres - construção, interfaces e perspectivas no Brasil - Volume III. São Carlos: CRESS-RJ: RiMA Editora, 2013, p. 23-37.

Estudos Geográficos, Rio Claro, 17(1): 6-31, jan./jun. 2019 (ISSN 1678—698X) http://www.periodicos.rc.biblioteca.unesp.br/index.php/estgeo 
- Da norte da Quimera à procura de Pégaso: a importância da interpretação sociológica na análise do fenômeno denominado desastre. In: VALENCIO, N.; SIENA, M; MARCHEZINI, V.; GONÇALVES, J. (Org.). Sociologia dos Desastres: construção, interfaces e perspectivas no Brasil. São Carlos: RiMa, 2009, v. 1, pp. 3-18.

WANDERLEY, L. Indícios de Racismo Ambiental na tragédia de Mariana: resultados preliminares e nota técnica. Poemas, UFRJ, Relatório Preliminar, 2015.

WANDERLEY, L.; MANSUR, M.; PINTO, R. Avaliação dos antecedentes econômicos, sociais e institucionais do rompimento da barragem da Samarco/Vale/BHP em Mariana (MG). In: MILANEZ, B.; LOSEKANN, C. Desastre no vale do rio doce: Antecedentes, impactos e ações sobre a destruição. Rio de Janeiro: Ed. Folio Digital: Letra e imagem, 2016, pp. 39-90.

WATTS, M. Petro-violence: Some thoughts on community, extraction, and political ecology", WorkingPapers. Berkeley, Institute of International Studies, 1999.

ZHOURI, A.; BOLADOS, P.; CASTRO, E (Org). Mineração na América do Sul. Neoextrativismo e lutas territoriais. São Paulo: Annablume, 2016a.

ZHOURI, A; VALENCIO, N; OLIVEIRA, R; ZUCARELLI, M; LASCHEFSKI, K; SANTOS, A. O desastre da Samarco e a política das afetações: classificações e ações que produzem o sofrimento social. Ciência \& Cultura, v. 68, n. 3, São Paulo July/Sept. 2016b, p. 36-40.

Estudos Geográficos, Rio Claro, 17(1): 6-31, jan./jun. $2019 \quad$ (ISSN $1678-698 X)$ http://www.periodicos.rc.biblioteca.unesp.br/index.php/estgeo 